\title{
Assessment of climate and land use change impacts with SWAT
}

\author{
Valentina Krysanova $\cdot$ Raghavan Srinivasan
}

Received: 13 November 2014 / Accepted: 29 November 2014/Published online: 27 December 2014

(C) Springer-Verlag Berlin Heidelberg 2014

\section{SWAT model}

The Soil and Water Assessment Tool (SWAT) is a deterministic continuous-time semi-distributed hydrological model for application at the river basin scale. The model was developed by the USDA Agricultural Research Service in the early 1990s based on Simulator for Water Resources in Rural Basins (SWRRB) and including routing procedures from Routing Outputs To Outlet (ROTO) too1 (Arnold et al. 1995, 1998).

SWAT is initialized by spatially distributed data on topography, land use/land cover, soils, land management and climate. The spatial disaggregation scheme includes subbasins delineated based on topography, which are further subdivided into nonspatial hydrological response units using the principle of similarity.

Several versions of GIS interface were developed for SWAT enabling the model parametrization and initialization from maps and related data, starting from a GRASS GIS version (Srinivasan and Arnold 1994) to the current ArcGIS 10.1/10.2.2 interface version. From the early 1990s, the SWAT model has undergone continuous testing, review, modifications and enhancement of many modules (Arnold et al. 1998; Neitsch et al. 2004, 2005; Gassman et al. 2007).

The model is process-based and simulates water flows in soil and groundwater, crop/vegetation growth, nutrient

\footnotetext{
V. Krysanova ( $₫)$

Potsdam Institute for Climate Impact Research (PIK), PO Box 601203, Telegrafenberg, 14412 Potsdam, Germany e-mail: krysanova@pik-potsdam.de

R. Srinivasan

Texas A\&M University, College Station, TX 77843, USA

e-mail: r-srinivasan@tamu.edu
}

cycling, erosion, pesticides, bacteria, lateral flows of water, sediments and nutrients, as well as environmental impact of land management practices on the main model outputs. A number of agricultural practices can be simulated, such as fertilizer and manure application, tillage, irrigation, subsurface drainage, buffer strips, as well as wetlands and ponds. The river routing component in SWAT routes the simulated water flows, sediments, nutrients, pesticides and bacteria along the river network in a basin. The reservoir module accounts for transformation of water fluxes, nutrients and sediments when passing the reservoir. The main model outputs include water, sediments, nutrients, pesticides and bacteria yields that can be provided for every subbasin outlet at a daily time step.

The SWAT tool belongs to a family of models, with several versions that are currently being distributed (see more information in Douglas-Mankin et al. 2010 and on the SWAT website: http://swat.tamu.edu/). Besides, several currently applied models were developed based on SWAT and still have many similar or identical components. The main reasons for this development were to adapt the model to other data formats outside USA, to modify/enhance some specific components, and to add new components. Among them are the following: the SWIM model (Soil and Water Integrated Model) (Krysanova et al. 1998, 2000), aiming mainly at climate and land use change impact assessment at a large regional scale; the ESWAT model (van Griensven and Bauwens 2005) with an adjustment for the hourly time step; the ALMANAC model (Kiniry et al. 2008) focused on simulation of crops, perennial grasses and forest ecosystems including successional changes; the coupled surface and groundwater model SWAT-MODFLOW (Kim et al. 2008); and the APEX model (Gassman et al. 2010) developed for assessment of various agricultural management strategies and accounting for economical costs. 


\section{Assessment of water resources with SWAT}

There are numerous SWAT applications for water resources assessment reported in the literature. The research questions of published articles are related to the analysis of river discharge, surface water and groundwater dynamics, snow and glacier dynamics, impoundment, irrigation practices, water management, erosion processes and sediment losses, nonpoint source pollution, best management practices in agriculture, land use change impacts, climate change impacts, and combined climate and land use change impacts.

The overviews of SWAT-based publications can be found in Gassman et al. 2007; Douglas-Mankin et al. 2010; Tuppad et al. 2011; Gassman et al. 2014, and many articles can be found in the SWAT literature database online (http://swat.tamu.edu/publications/swat-literature-database). Gassman et al. (2007) summarized SWAT-based studies worldwide which are described in more than 250 referred journal articles. Douglas-Mankin et al. (2010) provided an overview of the model performance statistics for hydrological processes in numerous SWAT applications. Tuppad et al. (2011) also summarized the reported model performance and reviewed several new developments. The SWAT literature database includes many papers structured by model version, topic and year of publication. The topics include also impact assessments covered in this Journal Issue, namely: climate change impact, land use change impact, as well as combined climate and land use change impact assessment. The number of publications on impact assessment in the database is growing: from only three in 2001 to 77 in 2013 and 83 in 2014 until November (estimation was done choosing only SWAT model, not other SWAT versions). Until now, the SWAT-based papers are published in 416 different journals with varying impact factors, and many papers are ranked as most highly cited papers in a number of journals.

The objective of this overview is to introduce five $r$ esearch articles published in this Special Section, which present different applications of SWAT covering the following themes: impacts of climate change, impacts of land cover change and combined impacts of climate change and human intervention in water management. This Special Section is mainly based on presentations at the International SWAT Conference held in July 2012 in New Delhi, India.

\section{Overview of included papers}

This section presents an overview of five papers included in this Special Section. One paper (Wagner et al. 2015) is devoted to testing of a new climate downscaling method and applying it in an Indian catchment; two papers present results of climate change impact studies at the large regional scale in Germany and USA (Huang et al. 2015; Jha et al. 2015); one paper investigates the combined impacts of climate change and human intervention in water management on water flows in a catchments in Iran (Vaghefi et al. 2015); and one paper is dealing with land use change impacts on water and sediment flows in China (Bieger et al. 2015). Four of the papers applied SWAT and one SWIM as the tools for impact assessment. In two studies, climate scenarios from only one climate model were used (Wagner et al. 2015; Vaghefi et al. 2015), whereas the ensembles of climate scenarios were applied in two other climate impact studies (Jha et al. 2015; Huang et al. 2015).

The study of Wagner et al. (2015) suggests a new climate downscaling approach based on the assumption that climate in future can be represented by rearranging observed climate data in the reference period. For that, firstly a bias correction is applied to the regional climate model (COSMO-CLM, in this case) data, and then for every week in the scenario period, the best-matching week (in terms of temperature and precipitation) in the baseline period is found using the suggested similarity index. The approach was applied for exploring climate change impacts on water balance components in a catchment in India $\left(2,036 \mathrm{~km}^{2}\right)$. The study concluded that the storage capacity of the large reservoirs in the area would not be met under warmer climate more frequently, which may have severe consequences for agriculture, energy production and other water users. A limitation of the method consists in difficulties to represent temperatures in the last 20 years of the scenario period due to the fixed range of observed values in the reference period, suggesting that the method should be applied to the near future (e.g. mid of the century) only, with moderate increases in temperature.

The paper of Jha et al. (2015) describes an analysis of climate change impacts on water yield and nitrogen loading in the Upper Mississippi River basin $\left(492,000 \mathrm{~km}^{2}\right)$ for the mid of the century. The study used an ensemble of ten general simulation models (GCMs) to drive SWAT. According to the modelling results, a higher discharge in winter months and a lower discharge in summer months (with up to a $41 \%$ decrease in July) can be expected. On the average annual basis, a $5 \%$ decrease in streamflow is projected. A small increase in the nitrogen load was projected on average over the entire basin $(1 \mathrm{~kg} / \mathrm{ha})$, with some variation from positive to negative changes in outputs at the subwatershed level.

The study of Huang et al. (2015) evaluated the performance of an ensemble of climate scenarios for projection of floods and droughts in Germany $\left(357,021 \mathrm{~km}^{2}\right)$ using the SWIM model and trying to detect the robust trends. It 
was concluded, with a moderate certainty, that most rivers in the country would experience more extreme 50-year floods and more frequent occurrences of 50-year droughts under warmer climate in this century. The robust results with a high certainty comprise: (a) an increasing trend in floods in the Elbe basin; (b) more frequent extreme droughts in the Rhine basin at the end of the century; and (c) more extreme floods and less frequent droughts in the basins of alpine rivers in the mid of the century. Besides, it was concluded that using climate scenarios from a subset of RCMs, performing best in the historical period, does not provide more certain projections. Therefore, an application of the whole ensemble of scenarios, which allows estimating the "full" range of uncertainties originating from climate input, could be recommended.

An integrated modelling approach coupling the SWAT and MODSIM models was applied in the study done by Vaghefi et al. (2015). They evaluated impacts of warmer climate and changes in cropping patterns on agricultural production and hydroenergy in a semiarid river basin in south-western Iran $\left(51,000 \mathrm{~km}^{2}\right)$. The climate scenarios from the Canadian GCM were applied. The outputs of the application of climate and land use change scenarios show a large variation in the total wheat yield, as well as potential increases and decreases in energy production. The results of the study suggest that changes in cropping patterns could be used as an effective tool for adaptation to negative consequences of climate change in terms of water availability.

The study by Bieger et al. (2015) is devoted to impacts of land use change on water balance components and sediment transport in a catchment located upstream of the Three Gorges Dam on the Yangtze River in China. The current changes in land use in the upstream areas are due to the resettlement of people and relocation of agricultural areas from valleys to steep, formerly forested slopes. The Xiangxi catchment (drainage area $3,200 \mathrm{~km}^{2}$ ) was chosen as a case study. In this catchment, the area of cropland decreased, and forested areas and area of orange orchards (which are assumed to provide better soil protection than crops) increased in the period 1987-2007 (not fully corresponding to the overall trends in the area). The simulation results show a small reduction in surface runoff and streamflow, and a moderate reduction in soil erosion and sediment loads. However, the scenario simulations indicate that the positive effects of afforestation on sediment flows could be outweighed by the negative influences in case of intensification of agriculture in the catchment and that an extension of agriculture to sloping land could lead to an increase in surface runoff and sediment yields.

The development of SWAT continues, and five papers included in this Special Section represent a valuable contribution to regional impact assessment studies in North
America, Europe and Asia. The model is widely recognized as an integrated tool for multidisciplinary studies and climate and land use change impact assessment at the regional scale in different physiographic and climatic conditions. It is now one of the most widely applied models for the river basin scale.

Besides, the SWAT and SWIM models are now involved in the Inter-Sectoral Impact Model Intercomparison Project (ISI-MIP), Phase 2 (see www.isi-mip.org and Warszawski et al. 2013). This project is aimed in establishing a systematic, long-term, cross-sectoral and community-driven impact model improvement and intercomparison process. The following sectors are included: water, agriculture, biomes/forestry, biodiversity, health, coastal infrastructure, permafrost, ocean carbon cycle, marine ecosystems and fisheries, and energy. The intercomparison of climate change impacts for several sectors using an ensemble of climate scenarios and applying a set of global and regional impact modelling tools has already started, and first results based on application of global models are already published in the Proceedings of the National Academy of Sciences, issue 111, 2013. It is expected that this project will enable a synthesis of our knowledge about the biophysical and socio-economic impacts of climate change at different levels of global warming.

\section{References}

Arnold J, Williams J, Maidment D (1995) Continuous-time water and sediment-routing model for large basins. J Hydraul Eng 121:171-183. doi:10.1061/(ASCE)0733-9429(1995)121:2(171)

Arnold JG et al (1998) Large area hydrologic modeling and assessment part I: model development. J Am Water Res Assoc 34(1):73-89

Bieger K, Hörmann G, Fohrer N (2015) The impact of land use change in the Xiangxi catchment (China on water balance and sediment transport. Reg Environ Chang. doi:10.1007/s10113013-0429-3

Douglas-Mankin KR, Srinivasan R, Arnold JG (2010) Soil and water assessment tool (SWAT) model: current developments and applications. Trans ASABE 53:1423-1431

Gassman PW, Reyes MR, Green CH, Arnold JG (2007) The soil and water assessment tool: historical development, applications, and future research directions. Trans ASABE 50(4):1211-1250

Gassman PW, Williams JR, Wang X, Saleh A, Osei E, Hauck LM, Izaurralde RC, Flowers JD (2010) The agricultural policy/ environmental extender (APEX) model: an emerging tool for landscape and watershed environmental analyses. Trans ASABE 53(3):711-740

Gassman PW, Sadeghi AM, Srinivasan R (2014) Applications of the SWAT model special section: overview and insights. J Environ Qual 43:1-8

Huang SH, Krysanova V, Hattermann F (2015) Projections of climate change impacts on floods and droughts in Germany using an ensemble of climate change scenarios. Reg Environ Chang. doi:10.1007/s10113-014-0606-z 
Jha MK, Gassman PW, Panagopoulos Y (2015) Regional changes in nitrate loadings in the Upper Mississippi River basin under predicted mid-century climate. Reg Environ Chang. doi:10.1007/ s10113-013-0539-y

Kim NW, Chung IM, Won YS, Arnold JG (2008) Development and application of the integrated SWAT-MODFLOW model. J Hydrol 356:1-16. doi:10.1016/j.jhydrol.2008.02.024

Kiniry JR, Macdonald JD, Kemanian AR, Watson B, Putz G, Prepas EE (2008) Plant growth simulation for landscape-scale hydrological modelling. Hydrol Sci J 53(5):1030-1042. doi:10.1623/ hysj.53.5.1030

Krysanova V, Müller-Wohlfeil D-I, Becker A (1998) Development and test of a spatially distributed hydrological/water quality model for mesoscale watersheds. Ecol Model 106:261-289. doi:10.1016/S0304-3800(97)00204-4

Krysanova V, Wechsung F, Arnold J, Srinivasan R, Williams J (2000) SWIM (soil and water integrated model). User manual, PIK report 69. Potsdam Institute for Climate Impact Research, Potsdam

Neitsch SL, Arnold JG, Kiniry JR, Srinivasan R, Williams JR (2004) Soil and water assessment tool input output, file documentation. Version 2005. Temple, Tex.: USDA-ARS Grassland Soil and Water Research Laboratory

Neitsch SL, Arnold JG, Kiniry JR, Williams JR (2005) Soil and water assessment tool theoretical documentation. Version 2005. Temple, Tex.: USDA-ARS Grassland Soil and Water Research Laboratory
Srinivasan R, Arnold JG (1994) Integration of a basin-scale water quality model with GIS. JAWRA 30(3):453-462. doi:10.1111/j. 1752-1688.1994.tb03304.x

Tuppad P, Douglas-Mankin KR, Lee T, Srinivasan R, Arnold JG (2011) Soil and water assessment tool (SWAT) hydrologic/water quality model: extended capability and wider adoption. Trans ASABE 54(5):1677-1684

Vaghefi SA, Mousavi SJ, Abbaspour KC, Srinivasan R, Arnold JR (2015) Integration of hydrologic and water allocation models in basin-scale water resources management considering crop pattern and climate change: Karkheh River Basin in Iran. Reg Environ Chang. doi: 10.1007/s10113-013-0573-9

van Griensven A, Bauwens W (2005) Application and evaluation of ESWAT on the Dender basin and the Wister Lake basin. Hydrol Process 19(3):827-838. doi:10.1002/hyp.5614

Wagner PD, Reichenau TG, Kumar SH, Schneider K (2015) Development of a new downscaling method for hydrologic assessment of climate change impacts in data scarce regions and its application in the Western Ghats, India. Reg Environ Chang. doi: 10.1007/s10113-013-0481-z

Warszawski L, Frieler K, Huber V, Piontek F, Serdeczny O, Schewe J (2013) The Inter-Sectoral Impact Model Intercomparison Project (ISI-MIP). Proc Natl Acad Sci 111(9):3228-3232. doi:10.1073/ pnas. 1312330110 